Vol 1 No 22020 Desember 2020

Jurnal AlphaEuclidEdu

Received: 21/10/2020; Revised: 30/11/2020; Accepted: 06/12/2020

\title{
POTENSI BERPIKIR KRITIS SISWA DALAM MENYELESAIKAN MASALAH PADA MATERI TRIGONOMETRI
}

\author{
1*Halimatussa'diah, ${ }^{2}$ Sugiatno, ${ }^{3}$ Ijuddin, Romal \\ 1,2,3Pendidikan Matematika FKIP Universitas Tanjungpura Pontianak \\ Email: halimatussadiah961@gmail.com
}

\begin{abstract}
Mathematics learning has an essential role in forming and developing students' critical thinking skills. It is in line with the objectives of learning mathematics, which shows a logical, critical, analytical, careful, and thorough, responsible, responsive, and not easily give up in solving problems. Mathematics taught to students has the aim to equip students to have critical abilities. But in reality, the implementation of mathematics learning in schools has not been able to train students' critical thinking skills. This study aims to describe and find out the potential of students' critical thinking in solving problems in trigonometry in high school. The research method used in this research is descriptive with exploratory research. The subjects in this study were 30 subjects. Based on the results of this study, it was found that the potential for students' critical thinking in solving trigonometry problems was medium. Potential students' critical thinking is categorized as being because students have not been able to understand the problem displayed correctly, students have difficulty in giving arguments or reasons for the answers they have stated, students cannot identify and choose relevant information because of the available mathematical models, students have difficulty in giving questions to the information displayed.

Keyword: Critical Thinking, Potential, Trigonometry
\end{abstract}

\section{Pendahuluan}

Pada dasarnya setiap manusia memiliki banyak potensi di dalam dirinya hanya saja potensi tersebut tidak dilatih atau tidak dikembangkan lagi hingga menjadi sebuah kemampuan. Kemampuan yang terdapat di dalam diri manusia yang dapat dikembangkan lagi menjadi lebih baik dengan sarana dan prasarana yang tepat dan baik dapat disebut dengan potensi (Habsari : 2005). Sedangkan menurut Pihadhi (Muchlisin: 2013) potensi bisa dikatakan sebagai kekuatan, energi atau kemampuan terpendam yang dimiliki manusia yang belum dimanfaatkan secara optimal.

Satu diantara potensi yang dimiliki oleh setiap manusia yaitu berpikir kritis. Berpikir kritis merupakan salah satu kemampuan berpikir tingkat tinggi (higher order thinking). Glaser berpendapat bahwa berpikir kritis merupakan kegiatan berpikir secara mendalam yang berhubungan dengan masalah dan hal-hal yang berada dalam jangkauan pengalaman seseorang yang dalam penyelesaiannya menggunakan metode pemeriksaan dan penalaran yang logis (Fisher, 2008:3).

Menurut Gokhale (Heris, Euis, dan Utari, 2017) mendefinisikan istilah berpikir kritis sebagai berpikir yang melibatkan kegiatan menganalisis, mensintesa, dan mengevaluasi konsep. Dalam berpikir kritis terlibat kegiatan memanipulasi data-data dan informasi yang ada menjadi lebih bermakna. Berpikir kritis adalah sebuah aplikasi untuk membuat alasan yang cermat dalam menentukan apakah suatu pernyataan itu benar atau tidak dan dapat mengevaluasi pernyataan tersebut (Richard dan Brooke, 2008). 
Vol 1 No 22020 Desember 2020

Jurnal AlphaEuclidEdu

Received: 21/10/2020; Revised: 30/11/2020; Accepted: 06/12/2020

Berdasarkan uraian para ahli dapat diketahui bahwa potensi berpikir kritis merupakan kemampuan dasar yang dimiliki manusia, kemampuan untuk menganalisis, membedakan, mencari hubungan dan dapat membuat argumen yang cermat untuk menentukan apakah suatu pernyataan tersebut benar atau tidak serta dapat mengevaluasi pernyataan tersebut. Keterampilan berpikir kritis merupakan keterampilan yang sangat penting untuk dikuasai oleh siswa agar siswa terampil dalam menyusun sebuah argument dan memeriksa kredibilitas sebuah sumber dalam membuat keputusan. Salah satu alat untuk mengembangkan kemampuan berpikir siswa yaitu, dengan pembelajaran matematika.

Pembelajaran matematika berperan penting dalam membentuk dan mengembangkan kemampuan berpikir kritis karena sejalan dengan tujuan pembelajaran matematika. Adapun salah satu tujuan pembelajaran matematika yaitu menunjukkan sikap analitis, kritis, logis, teliti, cermat, bertanggung jawab, responsive, dan tidak mudah menyerah dalam memecahkan masalah (Permendiknas, 2016). Pelajaran matematika yang diberikan di sekolah bertujuan untuk membekali siswa memiliki kemampuan kritis. Namun kenyataannya, melatih kemampuan berpikir kritis dalam kegiatan pembelajaran matematika di sekolah belum sepenuhnya terlaksana dengan baik Sampai saat ini pengembangan kemampuan berpikir kritis siswa masih relatif rendah.

Berdasarkan penelitian yang dilakukan Octavia (2015) kamampuan berpikir kritis siswa ditinjau dari aspek interpretation pada indikator mengklarifikasi maksud tegolong dalam kategori masih rendah dengan presentase $55,13 \%$. Sedangkan pada penelitian yang sejalan dengan Octavia yaitu kemampuan berpikir kritis siswa ditinjau dari aspek explanation dalam menyelesaikan masalah perbandingan di SMP yang dilakukan Feridia (2017) pada indikator menyajikan argumen tergolong dalam kategori sedang dengan presentase $41,35 \%$.

Satu diantara materi yang dapat mengembangkan potensi berpikir kritis siswa adalah trigonometri. Berdasarkan kurikulum 2013, trigonometri merupakan salah satu materi matematika peminatan yang diberikan di SMA kelas X IPA dan kelas XI IPA bahkan trigonometri masih dipelajari sampai kelas XII IPA. Selain menjadi menjadi mata pelajaran di sekolah trigonometri juga merupakan materi matematika yang banyak diterapkan dalam kehidupan sehari-hari. Mengingat pentingnya belajar trigonometri siswa diharapkan mampu menguasai materi dengan benar dan melalui materi trigonometri siswa diharapkan mampu mengembangkan potensi berpikir kritis yang dimilikinya. Namun kenyataan di lapangan masih banyak siswa kebingungan dalam menyelesaikan soal trigonometri yang diberikan.

Berdasarkan hasil pengamatan peneliti pada Praktek Pengalaman Lapangan (PPL) ketika guru menanyakan pada siswa. Berapa jumlah besaran pada segitiga? hampir semua siswa di dalam kelas menjawab $180^{\circ}$. Lalu guru menggambar 3 buah segitiga kecil, sedang 
Vol 1 No 22020 Desember 2020

Jurnal AlphaEuclidEdu

Received: 21/10/2020; Revised: 30/11/2020; Accepted: 06/12/2020

dan besar. Kemudian guru bertanya kembali Kira-kira jumlah besaran sudut pada segitiga kecil berapa? Pada segitiga sedang berapa? Pada segitiga yang besar berapa? ada beberapa orang siswa menjawab $45^{\circ}, 90^{\circ}$, dan $180^{\circ}$ dari jawaban siswa tersebut diketahui bahwa beberapa siswa terkecoh pada ukuran segitiga dalam menjawab jumlah besaran sudut pada segitiga. Untuk memperkuat data mengenai masalah yang terjadi pada siswa, peneliti melakukan pra-riset. Berdasarkan hasil pra-riset yang dilakukan pada 5 siswa kelas hanya 2 dari 5 siswa tersebut yang dapat menjawab soal dengan nilai di atas rata-rata yang telah ditentukan oleh sekolah. Berdasarkan hasil pekerjaan siswa diketahui bahwa 3 siswa tersebut tidak tepat dalam menyatakan dan tidak dapat menjelaskan dengan benar padahal menyatakan dan menjelaskan merupakan salah satu indikator berpikir kritis.

Pra-riset yang dilakukan belum menggunakan sampel yang menggambarkan potensi berpikir kritis seluruh siswa. Terutama untuk siswa yang ada di SMA Negeri 1 Sungai Ambawang belum pernah menjadi sampel dalam studi mengenai berpikir kritis. Karena peneliti penasaran mengenai potensi berpikir kritis siswa dalam menyelesaikan masalah trigonometri di SMA Negeri 1 Sungai Ambawang maka maksud dari riset ini adalah untuk mendeskripsikan potensi berpikir kritis siswa dalam menyelesaikan masalah pada materi trigonometri di Sekolah Menengah Atas.

Kemampuan dasar berpikir kritis siswa dapat dilihat dengan indikator-indikator yang telah dikemukan oleh beberapa ahli, salah satunya menurut Richard Parker dan Brooke Noel Moore (2008 : 5) terdapat tiga indikator dasar berpikir kritis, yaitu : 1). claim merupakan elemen dasar berpikir kritis, claim adalah suatu pernyataan yang kita ucapkan dengan tegas atau yang dituangkan dalam tulisan untuk menyampaikan informasi, mengekspresikan pendapat kita atau kepercayaan. Pernyataan juga dapat diartikan sebagai sikap seseorang terhadap suatu informasi; 2). Argumen adalah alasan logis yang mendukung sebuah pernyataan untuk menentukan kebenaran suatu pernyataan dan dapat diterima oleh banyak orang, argumen unsur terpenting dalam pemikiran kritis karena kesimpulan dari argumenlah yang dapat menyatakan posisi dari suatu pernyataan. Argumen yang baik adalah argumen yang dapat dipertanggung jawabkan dan beralasan (Jack, Stuart dan Mary, 2012:06); 3). Issue adalah pertanyaan yang dapat diajukan oleh seseorang terhadap suatu informasi yang baru diketahui atau informasi yang sudah ia ketahui namun disajikan dalam bentuk yang berbeda terlepas dari pernyataan tersebut benar atau salah. Isu dapat juga diartikan sebagai pertanyaan baru yang dapat muncul setelah seseorang melihat atau mendapat informasi.

\section{Metode Penelitian}

Metode deskriptif adalah metode yang digunakan dalam penelitian ini. Metode deskriptif merupakan metode penelitian yang menggambarkan atau menginterpretasikan 
Vol 1 No 22020 Desember 2020

Jurnal AlphaEuclidEdu

Received: 21/10/2020; Revised: 30/11/2020; Accepted: 06/12/2020

objek sesuai dengan apa yang terjadi (Sukardi, 2013). Sementara itu menurut Nazir (2017 : 43) untuk meneliti suatu kelompok manusia atau suatu objek dalam suatu set kondisi atau sistem pemikiran ataupun suatu kelas peristiwa pada masa sekarang, metode deskriptif merupakan metode yang sangat cocok untuk digunakan dalam penelitian ini. Pendekatan dalam penelitian ini adalah mix methods. Mix methods merupakan metode penelitian yang menggabungkan metode penelitian kualitatif dan kuantitatif dalam suatu kegiatan penelitian (Sugiyono, 2011).

Berdasarkan masalah dalam penelitian ini, penelitian eksploratif adalah bentuk penelitian yang digunakan peneliti dalam penelitian ini. Penelitian eksploratif adalah penelitian yang menggambarkan apa yang sedang terjadi yang berhubungan dengan siapa, kapan dan dimana, ataupun yang berhubungan dengan karakteristik suatu gejala atau masalah sosial. Pertanyaan tersebut dimaksudkan untuk mengetahui suatu gejala atau peristiwa yang terjadi. Pertanyaan tersebut merupakan pendalam terhadap berbagai hal yang berhubungan dengan gejala yang ada. Pendalam yang dilakukan tidak sistematis dan terkontrol yang artinya tidak berdasarkan hipotesis dan sampel dalam jumlah yang pasti (Mudjiyanto, 2018).

Menurut Given untuk mencari faktor penting penyebab timbulnya kesukaran dapat menggunakan penelitian eksplorasi. Penelitian eksplorasi dapat digunakan sebagai langkah awal untuk merumuskan persoalan yang ada dimana pemecahan persoalan tersebut, dapat dipecahkan menggunakan jenis penelitian lainnya, Karena penelitian eksplorasi hanya mencari ide atau hubungan baru, sehingga tidak ada suatu perencanaan yang formal, jadi pelaksanaannya tergantung pada kepandaian dari peneliti (Mudjiyanto, 2018). Subjek pada penelitian ini adalah 30 siswa kelas XI IPA 1 SMA Negeri 1 Sungai Ambawang yang telah mempelajari materi Trigonometri. Objek dalam penelitian ini adalah berpikir kritis siswa dilihat dari tiga indikator, yaitu: claim, argument dan issue dalam menyelesaikan soal trigonometri.

Alat pengumpul data yaitu tes tertulis dan wawancara. Tahapan penelitian terdiri dari tiga tahapan, yaitu:

Tahap Persiapan

Tahapan yang dilaksanakan dalam tahap ini yaitu: (1). Melakukan pra-riset. Pra-riset dilakukan untuk studi pendahuluan yaitu memberikan tes kepada beberapa siswa di sekolah tersebut. Menyusun desain penelitian; (2). Membuat instrumen penelitian berupa kisi-kisi soal, soal tes berpikir kritis siswa, alternatif jawaban, pedoman penskoran dan pedoman wawancara; (3). Seminar desain penelitian; (4). Memperbaiki desain penelitian berdasarkan hasil seminar; (4). Melakukan validitas instrument; (5). Memperbaiki instrumen berdasarkan hasil validitas; (6). Melakukan uji coba instrument; (7). Menganalisis data hasil uji coba; (8). Memperbaiki instrumen penelitian berdasarkan hasil uji coba soal; (8). 
Vol 1 No 22020 Desember 2020

Jurnal AlphaEuclidEdu

Received: 21/10/2020; Revised: 30/11/2020; Accepted: 06/12/2020

Meminta izinan untuk melakukan penelitian; (9). Menentukan waktu pelaksanaan penelitian dengan berkonsultasi pada guru matematika di SMA Negeri 1 Sungai Ambawang.

Tahap Pelaksanaan

Tahapan yang dilakukan pada tahap ini yaitu: (1). Memberikan tes perpikir kritis dalam menyelesaikan masalah pada materi trigonometri kepada siswa kelas XI IPA 1 ; (2). Menganalisis hasil tes yang telah dikerjakan siswa; (3). Memilih beberapa siswa berdasarkan hasil tes untuk diwawancarai; (4). Melakukan wawancara mendalam pada siswa yang telah ditentukan berdasarkan hasil tes. Wawancara siswa dilakukan untuk menggali informasi lebih dalam mengenai potensi berpikir kritis siswa.

Tahap Akhir

Tahapan yang dilaksanakan pada tahap ini yaitu; (1) Mengumpulkan data penelitian berupa tes berpikir kritis dan wawancara; (2). Melakukan analisis jawaban siswa; (3). Melakukan analisis data hasil wawancara; (4). Mendeskripsikan hasil analisis tes berpikir kritis dan hasil wawancara; (5). Membuat kesimpulan dan saran; (6). Menyusun skripsi.

\section{Hasil Penelitian dan Pembahasan}

\subsection{Hasil Penelitian}

Untuk memaparkan potensi berpikir kritis siswa dalam menyelesaikan soal trigonometri berdasar tiga indikator, berdasarkan pada hasil penelitian yang telah dilaksanakan, sehingga didapatkanlah data yang diperlukan dalam menjawab rumusan masalah pada penelitian ini yakni: menyatakan hasil, Menyajikan argumen dan menyajikan pertanyaan mengenai informasi yang disajikan pada materi trigonometri oleh siswa SMA Negeri 1 Sungai Ambawang. Berikut akan dijabarkan terkait hasil penelitian dan pembahasan. Adapun tujuan dalam penelitian ini yakni untuk mendeskripsikan potensi berpikir kritis siswa dalam menyelesaian masalah pada materi trigonometri di Sekolah Menengah Atas. Sebanyak 30 siswa kelas XI IPA 1 SMA Negeri 1 Sungai Ambawang menjadi subjek dalam penelitian ini yang telah mempelajari materi Trigonometri, dengan jumlah soal 3 dan jenis soal essay. Tiap soal memiliki skor maksimal 6 dengan rentang skor 0 - 4 untuk indicator claim, $0-8$ untuk indicator argumen dan 0-6 untuk indicator issue.

\section{Tabel 1}

Hasil Penskoran Potensi Berpikir Kritis Siswa Dalam Menyelesaikan Masalah Pada Materi

Trigonometri di Sekolah Menengah Atas Tahun Ajaran 2019/2020.

\begin{tabular}{|c|c|c|c|c|}
\hline Indikator & Claim & $\begin{array}{c}\text { Argume } \\
\text { n }\end{array}$ & Issue & \multirow{2}{*}{ Jumlah } \\
\cline { 1 - 4 } Nomor Soal & $1 \& 2$ & $1 \& 2$ & 3 & \\
\hline
\end{tabular}


Vol 1 No 22020 Desember 2020

Jurnal AlphaEuclidEdu

Received: 21/10/2020; Revised: 30/11/2020; Accepted: 06/12/2020

\begin{tabular}{|c|c|c|c|c|}
\hline Jumlah Skor & 100 & 163.5 & 44 & 307.5 \\
\hline Skor Maksimum & 120 & 240 & 180 & 540 \\
\hline$\%$ & 2500 & 2043.75 & 733 & 1708.3 \\
\hline Rata-rata (\%) & 83 & 68 & 24 & 57 \\
\hline Kategori & Tinggi & Sedang & Rendah & Sedang \\
\hline
\end{tabular}

Berdasarkan tabel 1. diketahui bahwa potensi berpikir kritis siswa dalam menyelesaikan masalah pada materi trigonometri dikategorikan sedang dengan persentase $57 \%$. Sedangkan untuk masing- masing indikator berbeda-beda yakni: tinggi untuk indicator claim, sedang untuk indicator argumen dan rendah untuk indicator issue. 
Vol 1 No 22020 Desember 2020

Jurnal AlphaEuclidEdu

Received: 21/10/2020; Revised: 30/11/2020; Accepted: 06/12/2020

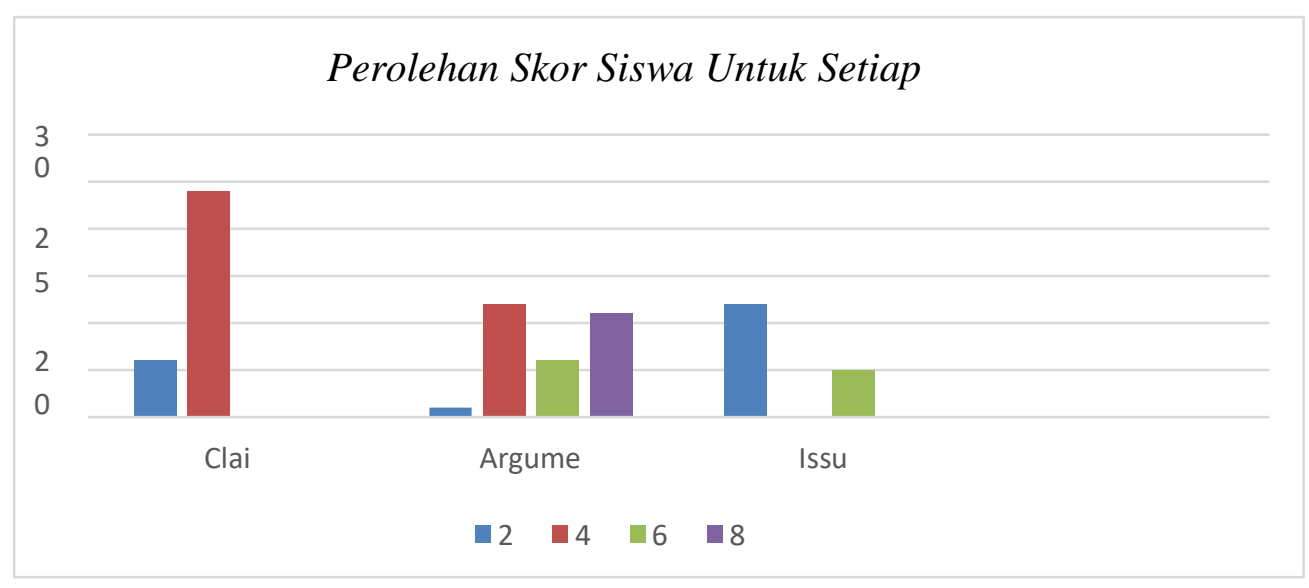

Berdasarkan diagram di atas diketahui bahwa pada indicator claim terdapat 6 siswa yang memperoleh skor 2 dan 24 siswa yang memperoleh skor 4 dengan rentang skor pada indicator claim adalah $0-4$. Pada indicator argumen terdapat 1 siswa yang memperoleh skor 2, 12 siswa yang memperoleh skor 4, 6 siswa yang memperoleh skor 6 dan 11 siswa yang memperoleh skor 8 dengan rentang skor pada indicator argumen 0 - 8. Pada indicator issue terdapat 12 siswa yang memperoleh skor 2 dan 5 siswa yang memperoleh skor 6 dengan rentang skor pada indicator issue adalah $0-6$.

\subsection{Pembahasan}

Potensi berpikir kritis siswa dalam menyelesaikan masalah pada materi trigonometri di sekolah menengah atas ini, peneliti mempunyai 3 indikator berpikir kritis, yaitu : claim, argumen, dan issue. Secara umum siswa kelas XI IPA 1 di SMA Negeri 1 Sungai Ambawang memiliki potensi berpikir kritis yang bisa dikategorikan sedang terlihat dari persentase rata-rata skor siswa yakni 57\%. Terdapat 4 siswa kategori tinggi, 15 siswa kategori sedang dan 11 siswa dengan kategori rendah. Dari 30 siswa terdapt 17 atau $56,67 \%$ siswa dapat mejawab semua soal yang telah diberikan meskipun ada beberapa siswa yang tidak dapat menjawab semua soal dengan benar. 15 siswa atau 50\% memperoleh skor 61-97 sedangkan 15 siswa lainnya memperoleh skor 28-56.

Berdasarkan hasil wawancara secara umum ditemukan bahwa berpikir kritis siswa dipengaruhi oleh beberapa factor, yaitu: pengalaman dan lingkungan. Hal ini sesuai dengan Skovsmose (2014) yang mengatakan bahwa masa depan ditentukan dengan banyak sekali parameter yang harus dilakukan dengan kondisi ekonomi, social-ekonomi, proses inklusi dan eksklusi, budaya, nilai-nilai dan tradisi, wacana public, dan rasisme. Selain itu, masa depan juga ditentukan melalui pengalaman orang tersebut. Hal ini adalah persiapan pendidikan matematika kritis untuk mengakui keragaman masa depan siswa dan untuk mengembangkan pendidikan matematika yang mungkin memberikan kemungkinan baru siswa. Sedangkan untuk masing-masing indikator tersebut siswa memperoleh skor berdeda-beda ada yang tinggi, sedang, dan rendah. Siswa dapat memperoleh skor tinggi, 
Vol 1 No 22020 Desember 2020

Jurnal AlphaEuclidEdu

Received: 21/10/2020; Revised: 30/11/2020; Accepted: 06/12/2020

sedang, dan rendah pada tes tersebut dipengaruhi oleh banyak faktor salah satunya pengalaman dan lingkungan belajar. Berikut akan dibahas mengenai proses berpikir kritis siswa berdasarkan indikator claim, argumen, dan issue.

Pada indikator claim peneliti memberikan 2 soal dengan soal yang berbeda. Berikut pembahasan dari indikator claim.

Hasil analisis pada soal nomor 1 dan 2 pada indikator claim ada 16 dari 30 siswa yang dapat menyatakan dengan benar. Sedangkan 14 siswa lainnya menyatakan soal nomor 1 atau nomor 2 saja yang benar. Banyak dari mereka salah dalam menyatakan soal nomor 2 . Setelah dilakukan wawancara kepada 3 siswa yang mendapat skor tinggi, sedang dan rendah pada indikator claim diketahui bahwa siswa yang memperoleh skor sedang salah menyatakan soal nomor 2 ia salah dalam menjumlahkan dan mengurangkan sudut pada segitiga $\mathrm{ABD}$, siswa yang memperoleh skor rendah salah dalam menggambarkan soal nomor 2 sehingga ia tidak dapat menyatakan soal nomor 2 benar atau tidak, sedangkan siswa yang memperoleh skor tinggi dapat menyatakan soal nomor 1 dan 2 dengan benar hanya saja dia menyatakan jumlah besaran sudut pada semua segitiga padahal yang ditanyakan hanya jumlah besaran sudut pada satu segitiga saja.

Siswa yang memperoleh skor tinggi tersebut saat ditanyakan ternyata dia sudah pernah mendapat soal yang kurang lebih sama seperti soal tersebut, sehingga dia dapat menjawab soal tersebut dengan lancar dan benar. Dia memperoleh soal tersebut di internet dia mengatakan bahwa di sekolah tidak pernah mendapat soal seperti itu sebelumnya. siswa yang memperoleh skor tinggi juga tergolong anak yang aktif dalam belajar di kelas maupun di rumah dia suka mencari soal-soal di internet lalu dikerjakannya sehingga dia terbiasa dengan soal-soal baru yang tidak diajarkan di sekolah. Siswa yang memperoleh skor sedang saat ditanyakan sebelumnya tidak pernah mendapat soal seperti yang peneliti berikan sehingga dia merasa sedikit bingung dalam mengerjakan soal tersebut, dia hanya dapat menyatakan 1 soal dengan benar. Saat belajar dia hanya mengerjakan soal- soal yang guru berikan saja. Sedangkan siswa yang memperoleh skor rendah saat ditanyakan sebelumnya juga tidak pernah mendapat soal seperti yang peneliti berikan sehingga dia merasakan kebingungan dalam menjawab soal seperti soal nomor 2 dia salah memahami maksud soal sehingga dia salah dalam menggambarkan soal tersebut, siswa yang memperoleh skor rendah tersebut di kelas merupakan siswa yang pasif saat proses pembelajaran bahkan dia juga tidak dapat menyatakan seseuatu ketika ditanyakan oleh guru mengenai pembelajaran ternyata hal ini biasa terjadi di rumah dia tidak pernah dimintai pendapat oleh orang rumah mengenai pembelajaran yang terjadi di sekolah. Hal ini lah yang mungkin mempengaruhi dia dalam pembelajaran.

Berpikir kritis siswa pada soal nomor 1 dan 2 pada indikator claim tergolong tinggi berdasarkan hasil rata-rata skor pada indikator claim yakni 83\%. Terdapat 16 atau 53\% siswa dapat menyatakan hasil dengan benar. Terdapat 8 atau $27 \%$ siswa kurang tepat 
Vol 1 No 22020 Desember 2020

Jurnal AlphaEuclidEdu

Received: 21/10/2020; Revised: 30/11/2020; Accepted: 06/12/2020

dalam mengclaim soal nomor 1 dan 2 sedangkan 6 atau 20\% siswa lainnya hanya mengclaim 1 soal saja dari soal nomor 1 dan 2 .

Pada indikator argumen peneliti memberikan 2 soal dengan soal yang berbeda. Berikut pembahasan dari indikator argumen.

Hasil analisis pada soal nomor 1 dan 2 pada indikator argumen ada 5 dari 30 siswa yang dapat memberikan argumen dengan benar, 6 dari 30 siswa tidak tepat dalam memberikan alasan kenapa mereka menyatakan bahwa soal nomor 1 itu benar dan soal nomor 2 itu salah, 13 dari 30 siswa hanya dapat memberikan argumen pada 1 soal saja dan 5 siswa tidak memberikan argumen kenapa mereka dapat menyatakan benar dan salah. Setelah dilakukan wawancara kepada 3 siswa yang mendapat skor tinggi, sedang dan rendah pada indikator argumen diketahui bahwa siswa yang memperoleh skor timggi sebelumnya pernah mendapatkan soal yang kurang lebih sama seperti soal yang peneliti berikan dia mangatakan bahwa dia memperoleh soal tersebut di bimbingan belajar online yang dia ikuti sehingga dia bisa mengejakan soal tersebut dengan lancar.

Siswa yang memperoleh skor sedang ketika ditanyakan sebelumnya tidak pernah mendapatkan soal seperti yang peneliti berikan begitu juga dengan siswa yang mendapat skor rendah. Siswa yang memperoleh skor sedang salah dalam memberikan beragumen mengenai jumlah sudut segitiga ABD pada soal nomor 2 dia salah dalam menjumlahkan dan mengurangkan sudut pada segtiga tersebut karena argumen yang dia berikan salah maka dia juga salah dalam menyatakan soal nomor 2 .

Sedangkan siswa yang memperoleh skor rendah pada soal nomor 1 dia memberikan argumen yang tidak tepat mengapa dia menyatakan soal nomor 1 tersebut benar dan pada soal nomor 2 dia tidak menjawab. Ternyata di dalam proses pembelajaran siswa yang memperoleh skor tinggi merupakan siswa yang sering bertanya dan aktif dalam pembelajaran seperti dapat menyampaikan pendapat ketika ditanya oleh guru ataupun temannya, dia juga mengatakan bahwa di rumah dia sering dimintai pendapat mengenai pembelajaran dia di sekolah dan mengenai pekerjan rumah adik atau sepupunya bahkan dia sering mencari soal-soal di internet lalu mengerjakannya sehingga dia terbiasa dengan soal-soal baru yang bahkan tidak diberikan di sekolah hal inilah yang membuat dia dapat menjawab soal tersebut dengan benar. Siswa yang memperoleh skor sedang dan rendah di dalam kelas tergolong siswa yang pasif karena ketika dimintai pendapat oleh guru mengenai pembelajaran dia hanya sesekali dapat memberikan jawabannya. Ternyata menurut siswa yang mendapat skor sedang dan rendah ketika di rumah pun mereka seperti itu.

Berpikir kritis siswa pada soal nomor 1 dan 2 pada indikator argumen tergolong sedang berdasarkan hasil persentase rata-rata skor yakni $68 \%$. Terdapat 11 siswa atau $37 \%$ yang dapat memberikan berargumen mengenai apa yang telah dia claim pada soal nomor 1 dan 2 dengan benar, 6 atau 20\% siswa memberikan argumen mengenai apa yang telah dia 
Vol 1 No 22020 Desember 2020

Jurnal AlphaEuclidEdu

Received: 21/10/2020; Revised: 30/11/2020; Accepted: 06/12/2020

claim pada soal nomor 1 dan 2 namun kurang tepat dan 13 atau 43\% siswa lainnya hanya memberikan argumen pada salah satu soal saja dari 2 soal yang diberikan. Hal ini sesuai dengan penelitian yang dilakukan oleh Feridia (2017) mengenai kemampuan berpikir kritis pada aspek Explanation dengan indikator menyajikan argumen tergolong sedang yaitu $41,35 \%$ dan penelitian yang dilakukan oleh Nurhakim (2019) mengenai kemampuan berpikir kritis siswa sekolah menengah atas yaitu siswa yang mempunyai kemampuan berpikir kritis matematik sedang, siswa dapat mengungkapkan atau membuat kesimpulan. Pada indikator issue peneliti menyiapkan 1 soal. Berikut pembahasan dari indikator issue.

Hasil analisis pada soal nomor 3 pada indikator issue ada 1 dari 30 siswa yang mengajukan bertanyaan paling banyak yaitu 3 pertanyaan benar, 4 dari 30 siswa mengajukan 3 pertanyaan ada pertanyaan yang benar dan ada pertanyaan yang salah, 12 dari 30 siswa mengajukan 1 pertanyaan ada pertanyaan yang benar dan ada pertanyaan yang salah, dan 13 siswa yang lainnya tidak mengajukan pertanyaan. Setelah dilakukan wawancara kepada 3 orang siswa yang mendapat skor tinggi, sedang dan rendah pada indikator issue diketahui bahwa ketiga siswa tersebut tidak pernah memperoleh soal seperti yang peneliti berikan sebelumnya, namun 17 siswa dapat mengajukan pertanyaan mengenai gambar-gambar yang ditampilkan pada soal nomor 3. Siswa yang memperoleh skor tinggi dengan mengajukan 4 pertanyaan benar, berikut salah satu pertanyaan yang ia ajukan “Apakah segitiga 1, 2, dan 3 memiliki perbandingan sudut yang sama?" ketika ditanya kenapa kamu mengajukan pertanyaan tersebut dan kira-kira apa jawaban dari pertanyaan yang kamu ajukan,dia dapat menjelaskan kenapa dia mengajukan pertanyaan tersebut dan dia juga dapat memberikan jawaban dari pertanyaan yang telah dia ajukan. Dia dapat menegajukan pertanyaan paling banyak diantara teman-temannya yang lain karena dia terbiasa bertanya dan ketika ditanya oleh guru dia dapat menjawab pertanyaan yang guru berikan mengenai pembelajaran.

Siswa memperoleh skor sedang dengan mengajukan 1 pertanyaan. Berikut pertanyaan yang ia ajukan "Apakah sudut-sudut segitiga 1, 2, dan 3 memiliki besaran yang sama?" ketika ditanya kenapa kamu mengajukan pertanyaan tersebut dan kira-kira apa jawaban dari pertanyaan yang kamu ajukan, dia tidak dapat mengatakan alasan kenapa dia mengajukan pertanyaan tersebut namun mengetahui jawaban atas pertanyaan yang dia ajukan, namun jawaban tersebut kurang tepat. Dia mengatakan bahwa ketika pembelajaran di kelas hanya sesekali bertanya karena merasa malu untuk bertanya bahkan ketika di rumah juga hanya sesekali. Sedangkan siswa yang tidak mengajukan pertanyaan, ia mengatakan tidak tahu pertanyaan apa yang harus diajukan karena dia tidak terampil dan tidak biasa bertanya, bahkan ketika pembelajaran di kelas dia tidak pernah bertanya dan ketika ditanyakan oleh guru dia tidak dapat menjawab, ternyata ketika di rumahpun dia tidak pernah bertanya, dan juga tidak pernah ditanyakan oleh orang rumah mengenai pembelajarannya di sekolah. 
Vol 1 No 22020 Desember 2020

Jurnal AlphaEuclidEdu

Received: 21/10/2020; Revised: 30/11/2020; Accepted: 06/12/2020

Berpikir kritis siswa pada soal nomor 3 dengan indikator issue tergolong rendah berdasarkan hasil persentase rata-rata skor yakni 24\%. Hanya 5 atau $16 \%$ siswa yang dapat mengajukan 3-4 pertanyaan, 12 atau 40\% siswa yang dapat mengajukan 1 pertanyaan dan 13 siswa lainnya tidak mengajukan pertanyaan. Hal ini sejalan dengan penelitian yang dilakukan oleh rizka (2018) mengenai kemampuan berpikir kritis siswa pada aspek inference dengan indikator mempertanyakan fakta dikategorikan rendah yaitu $29 \%$ dan Rasiman (2015) Mengenai Tingkat Kemampuan Berpikir Kritis, pada level kurang kritis atau (LCTA-1) memiliki karakteristik sebagai berikut: Siswa dapat dengan jelas mengidentifikasi fakta, fakta yang diketahui atau fakta yang dipertanyakan.

\section{Kesimpulan}

Berdasarkan hasil analisis data dan pembahasan di atas, dapat kesimpulan bahwa potensi berpikir kritis siswa dalam menyelesaikan masalah pada materi trigonometri di SMA Negeri 1 Sungai Ambawang tergolong sedang terlihat dari persentase rata-rata skor siswa yakni 57\%. Berikut berpikir kritis siswa dalam menyelesaikan soal trigonometri pada indikator claim, argumen, dan issue.

4.1 Berpikir kritis siswa dalam menyelesaikan masalah trigonometri pada indikator claim tergolong tinggi dilihat berdasarkan hasil rata-rata skor pada indikator claim yakni $83,3 \%$.

4.2 Berpikir kritis siswa dalam menyelesaikan masalah trigonometri pada indikator argumen

tergolong sedang dilihat berdasarkan hasil rata-rata skor pada indikator argumen yakni $68 \%$.

4.3 Berpikir kritis siswa dalam menyelesaikan masalah trigonometri pada indikator issue tergolong rendah dilihat berdasarkan hasil rata-rata skor pada indikator Issue yakni $24 \%$.

\section{Referensi}

Feridia. (2017). Kemampuan Berpikir Kritis Ditinjau Dari Aspek Explanation Dalam Penyelesaian Masalah Perbandingan Di SMP: Universitas Tanjungpura Pontianak

Fisher, A. (2008). Berpikir Kritis : Sebuah Pengantar. Jakarta: PT. Gelora Aksara Pratama. Habsari, Sri. (2005). Bimbingan \& Konseling SMA Kelas XI. Jakarta: Grasindo.

Haris, Euis dan Utari. (2017). Hard Skills dan Soft Skills. Bandung: PT. Refika Aditama.

Jablonka, Eva. (2014). Critical Thinking in Mathematics Education. London: Department of Education and Professional Studies, King's College.

Jack, Stuart dan Mary. (2012). Critical Issues in Education : Dialogues and Dialectics. Mary Rose McCarthy: Foreword by Nel Noddings.

Muchlisin. (2013). Potensi Diri. [Online]. https://www.kajianpustaka.com/2013/10/potensidiri.html|?m=1. diakses 8 November 2019. 
Vol 1 No 22020 Desember 2020

Jurnal AlphaEuclidEdu

Received: 21/10/2020; Revised: 30/11/2020; Accepted: 06/12/2020

Mudjiyanto, B. (2018). Tipe Penelitian Eksploratif Komunikasi Eksploratory Research in Communication Study. Jakarta Pusat.

Nazir, Moh. (2017). Metode Penelitian. Jakarta : Ghalia Indonesia.

Octavia, S. (2015). Kemampuan Berpikir Kritis Berdasarkan Aspek Interpretation Di Sekolah Menengah Atas: Universitas Tanjungpura Pontianak

Permendiknas, (2016). Standar Isi. Jakarta: Depdiknas.

Purwanto. (2009). Evaluasi Hasil Belajar. Yogyakarta: Pustaka Belajar.

Richard dan brooke. (2008). Critical Thinking,Ninth Edition. Chico: McGraw-Hill Higher Education, California State University.

Sukardi. (2013). Metodologi Penelitian Pendidikan: Kompetensi dan Praktisnya. Jakarta: PT Bumi aksara.

Sugiyono. (2011). Metode Penelitian Kuantitatif, Kualitatif, dan R\&D. Bandung: Alfabeta. 
Vol 1 No 22020 Desember 2020

Jurnal AlphaEuclidEdu

Received: 21/10/2020; Revised: 30/11/2020; Accepted: 06/12/2020 